\title{
ASSOCIATION BETWEEN THERMAL COMFORT CONDITION AND WORSHIPPERS' SATISFACTION IN TIMBER AND CONCRETE OF SUBURBAN RELIGIOUS BUILDINGS
}

\author{
Fadhlizil Fariz ABDUL MUNIR*, Asniza Hamimi ABDUL THARIM, Asmalia CHE \\ AHMAD, Nur'Ain ISMAIL, Noraidawati JAAFAR
}

DOI: $10.21163 / G T \_2020.151 .22$

\begin{abstract}
:
Human thermal comfort is the paramount target to achieve the satisfaction of the occupation and users of the building. The frequency of use in the Malaysian religious building, known as mosque, changes daily in different hours and intervals. The first objective of this study is to compare the thermal comfort condition between timber and concrete religious building. The second objective is to analyze the relationship between thermal comfort and worshippers' perception level in the religious building. A questionnaire survey and case study was conducted at various religious buildings in suburban area of Kelantan, Malaysia. The 476 closed structured questionnaires have been given out, and a total of 173 surveys have been achieved. The answers have statically analyzed by using SPSS Version 23.0: descriptive analysis (mean ranking) and multiple regression analysis. The result shows that majority of the respondents have chosen the concrete mosque as their preference to perform prayer instead of timber mosque. It is hoped that this study will give benefit for worshippers towards thermal comfort to achieve the thermally comfortable environment in mosques building.
\end{abstract}

Key-words: Thermal Comfort, Religious Building, Concrete, Timber, Worshippers' Perception

\section{INTRODUCTION}

According to Jamaludin et al. (2015), Malaysia is considered as a tropical country and characterized as a warm and humid zone located between the tropics of Cancer and Capricorn and at a latitude of $1^{\circ}-7^{\circ} \mathrm{N}$ and longitude $100^{\circ}-119^{\circ} \mathrm{E}$. Due to its location and zone, Malaysia has high temperatures and humidity depending on the area and will experience warm and humid conditions every year. Qahtan et al. (2016) state that the average mean temperature in a day for this zone is 31.6 Celsius during the daytime and 24.6 Celsius during the night. In addition, the mean monthly relative humidity is $82 \%$ found in August and never falls below $75.79 \%$ in November. Besides, Malaysia is exposed to abundant sunshine as it is close to the equator. According to previous researches, the most climate impacts on Malaysia buildings are from the high intensity of solar radiation and air temperature with little wind movement and high relative humidity conditions which has greatly affected occupants' indoor thermal comfort in the building. This is supported by Qahtan et al. (2010) which describes Malaysia as a hot-humid tropical country that receives annual total radiation of above $4.31 \mathrm{kwh} / \mathrm{m}^{2}$ and 10 hours of sunshine per day which causes high indoor temperature that usually requires the installation of an air conditioner in the workspace. In March and May, Malaysia will have the most sunshine at over 200 hours

\footnotetext{
${ }^{*}$ Faculty of Architecture, Planning and Surveying, Universiti Teknologi MARA, Perak Branch, 32610, Perak, Malaysia, fariz170@uitm.edu.my
} 
each, and in November the sunshine will at least be at 150 hours. The high indoor temperature condition causes an increase in the demand for air conditioning in order to provide the necessary thermal comfort for the occupants. In most buildings, human's thermal comfort is the paramount target to achieve the satisfaction of the occupants and users. Inappropriate thermal comfort in mosques will lead to the unsuitable thermal environment for the worshippers and the functions held inside of the building. The mosque should provide an acceptable level of thermal comfort in order to seek serenity and focus during worship. In addition, a mosque should consider the importance of balancing an environmentally friendly surrounding, intelligent use of space, use of technology and modern materials to maximize the potential of the structure to be used in the best possible way (Asif et al., 2019). The variation in the building's design must consider the climate of the country, especially in the hot and humid areas to make sure the occupants are satisfied with the thermal comfort environment in the building. Hence, this study attempts to determine the influence of thermal comfort condition on worshippers' satisfaction in two different materials of the mosque, which are timber and concrete mosques.

\section{OVERVIEW OF RELIGIOUS BUILDING IN MALAYSIA}

The religious building in Malaysia is known as mosque, and in the Arabic language is known as 'masjid' which comes from the word 'sajd' which means 'sujud' (prostration) and 'sejadah' (prayer mat) (Nasir, 1984). The combination of these two words means an act of prostration by a person on a prayer mat. The mosque is an important physical symbol of Islam and the centre of Muslim activity. For Muslims, the mosque is a centre for learning about Islam, and it acts as a school, hence helping bind the community together. As a holy place, it functioned as a praying area to help to refine the souls and awaken their minds and hearts.

Mosques differ from other types of buildings. Mosques have an intermittent operation schedule which is wholly or partially yet periodically occupied due to five prayer times per day throughout the year. The five prayer times are known as Subuh (daybreak), Zohor (noon), Asar (midafternoon), Maghrib (sunset) and Isyak (evening) where it will start from early morning until night time with duration of approximately twenty minutes to an hour each to complete the prayer. Each of the prayers will be performed in a group and led by an Imam where the prayer has two to four cycles (rakah) containing a series of postures per rakah.

\subsection{Timber and Concrete as the Material for Mosque}

In the early period of Islam in Malaysia, mosque architecture was straightforward and did not possess clear features, such as large domes and decorated calligraphy from those in the Middle East. Zafrullah (2011) the typology of the mosque at the start of the design was built of wood and has pyramidal roof characters are layered in two or three floors and the roof using a screen stocking. Timber mosque architecture is very different from the modern mosque in aspects such as its small size, the use of timber as the primary building material, post and beam method of construction and decorated carved components. A distinctive difference is the carved ornamentation of the roof or within the building. The roofs were multi-tiered pyramidal formations and were prevalent throughout the Malay Peninsula, Sumatra, Java, Kalimantan, Brunei, the southern Philippines and the former kingdom of Champa in Cambodia.

In the Era of the British Colonialization (18th to 19th century), the drastic transformation in terms of architecture design in most buildings had led to the elimination 
of timber as a construction material. As replacements, the new materials were introduced, which were bricks, stone, cast iron and steel. According to Omer (2010), "the British for geopolitical reasons helped to build mosques that looked monumental and more like palaces than places of worship, to keep up with their reputation as colonial masters but also for the satisfaction of a local sultan". Malaysian mosque architecture underwent a drastic revolution from the time when its independence in 1957. The transformation in the architecture style of mosques during the British Era has shown the transformations between the traditional mosques in terms of scale and proportion, form, features and building materials.

\subsection{Thermal Comfort}

ASHRAE Standard 55 (2013) stated that thermal comfort is the condition of mind that expresses satisfaction with the thermal environment. In general, comfort is attained when body temperature is held within a narrow range, skin moisture is low, and the physiological effort of regulation is minimized. The human body will be affected and will lead to discomfort in cold environments when the body loses more heat to the environment and in hot environments when their body will not exert enough heat.

The thermal comfort is influenced due to many factors. There are two major factors that affect the thermal comfort level of the human body, which is the environmental and personal factor. Under the environmental factor, there are four factors that define the surrounding environment condition, while the latter two represent personal factors. These factors may be independent of each other but together contribute to thermal comfort. The most dominant factor affecting the thermal comfort is the air temperature and has been considered the major influencing factor to the thermal comfort, and many of the indexes produced are mainly focused on the determination of the comfort temperature (Maarof, 2014). The six factors affecting thermal comfort are both environmental and personal.

\subsubsection{Air Temperature}

The most dominant factor affecting thermal comfort is air temperature. This supported by Maarof (2014) described that the air temperature had been considered the major influencing factor to the thermal comfort and many of the indexes produced are mainly focusing to the determination of the comfort temperature. Air temperature is measured on how hot or cold the air is it and most commonly measured weather parameter. Temperature describes the kinetic energy, energy of motion and of the gases that make up air. The air temperature will increase, as gas molecules move more quickly. The previous studies have shown that air temperature is considered as the main factor among other factors of thermal comfort that influences the occupants' thermal comfort level. However, some of the studied show that the air temperature has less significant in influence the thermal comfort level. Maarof (2014) result shows that a change in the air temperature does not affect the comfort condition based on the feedback were given by the respondents.

\subsubsection{Air Velocity}

Air velocities are the impact on the rate of heat transfer between air and adjacent surfaces. It happens where the higher the velocity of the air moving across a surface, the higher the heat transfer will be. Air velocities in an indoor building affect the thermal comfort of people within spaces. The greater air velocity in building spaces, the greater will be the heat exchange between people in a space and the air around of them. In other occasions, a higher air velocity may be necessary for example; a fan might be turned on 
during hot climate/weather to increase the rate at where the body is able to lose heat to its surrounding areas. Under other circumstances, a fan may be undesirable, for example, in colder conditions when higher air velocities may be noticeable as a draught.

\subsubsection{Humidity}

Humidity is the mass of water vapours in a volume of air divided by the mass of dry air. For example, if the water is heated and it evaporates to the surrounding environment, it will result in the amount of water of the air will provide humidity. The high relative humidity is one of the biggest obstacles to tackle besides high air and mean radiant temperature for tropical countries, especially in the hot and humid regions (Maarof, 2014). High humidity environments have a lot of vapours in the air, which prevents the evaporation of sweat from the skin. In hot environments, humidity is important and necessary because less sweat evaporates it will be when humidity is high $(80 \%+)$. The evaporation of sweat is the main method of heat reduction.

\subsubsection{Radiant Temperature}

The mean radiant temperature is defined in ASHRAE Standard 55b (2004) as "the uniform surface temperature of an imaginary black enclosure in which an occupant would exchange the same amount of radiant heat as in actual non-uniform space". The Mean Radiant Temperature is the weighted mean temperature of the temperatures of the surfaces that form the border of the room, including the effect of incident solar radiation and its effects will transfer by radiation. Together with air temperature, mean radiant temperature is the major factor that affects the sensation of warmth as the radiation that falls on the skin stimulates the skin's sensory organs.

\subsection{Worshippers' Perception towards Thermal Comfort in Mosque}

According to Hussin et al. (2014), inappropriate thermal comfort in mosque buildings leads to the unsuitable thermal environment for the worshippers and the function held inside. Soemardiono et al. (2019) elaborated that people participation is the key factor in sustainable development. In order to increase participation, the building design should be appealing and suitable to the condition of the area. The worshipper needs to feel comfortable and relax to achieve quietness, harmony and peacefulness during prayer. Sezer and Kaymaz (2016) mentioned that the users' physical performance and tranquillity are influenced by the comfort conditions of the indoor environment. The environmental variables such as air temperature, humidity, air movement and heat transfer affect thermal sensation and satisfaction of occupants. In Malaysia, the use of air conditioning has been a trend in order to achieve thermal comfort. However, if the improper operation or control of the air-conditioning systems, thermal comfort may not be achieved (Al Homoud et al., 2009).

\section{METHODOLOGY}

The research objectives are divided into two: firstly, to identify thermal comfort condition in timber and concrete mosque building and secondly, to determine the differences between worshippers' perception level on thermal comfort in timber and concrete mosque building. In this research, the questionnaires were used to collect the data in order to determine the differences between worshippers' perception level on thermal comfort in timber and concrete and to analyze the relationship between thermal comfort and 
worshippers' satisfaction in mosque building. In obtaining this information, two approaches have been chosen: a survey (questionnaire) and observation (case study) method.

\subsection{Questionnaire Survey}

The survey was conducted to determine user expectations about comfortable thermal conditions in mosques and to what extent these expectations are met. The research aims to cover indoor temperature, humidity, air movement (ventilation), and heat transfer issues depending on the user responses. The survey is developed based on 5-point Likert scale ranging from strongly agree to strongly disagree. The survey questionnaires used in this research consists of two main sections: Background Information (Section 1) and Worshippers' Perception of Thermal Comfort in Mosque Building (Section 2). The second section of the questionnaire is divided into two parts where Part A emphasis on the independent variable (IV) of this research, which is Environmental Factors whilst Part B focuses on the worshippers' satisfaction as the indirect variable of the research. All items in Section 2 of the questionnaire survey were adapted and modified from previous research on indoor environmental quality (IEQ) (Tharim et al., 2018) and also taken from different literature on satisfaction research.

The scope of this study is limited to user comfort perception parameters of timber and concrete mosques. In ensuring the consistency, a survey was held in different material mosques that are naturally ventilated where the floor area range for these mosques are almost the same. They share a lot of similarities but mainly differ in the application of the material design, as discussed earlier. The 476 closed structured questionnaires have been given out, and a total of 173 surveys have been achieved, which is about $36 \%$ of the questionnaire have been received. The answers have statically analyzed by using SPSS version 23. The attained results are illustrated in graphs in the research result section.

\subsection{Case Study}

The case study was used to achieve objective one, which is to identify thermal comfort condition in timber and concrete mosque building. The first process in data collection is to evaluate the factor affecting the changes in the thermal condition inside the prayer hall of the mosques. The common practice is to measure the common factors affecting the thermal comfort, which are building design and ventilation system. The researcher evaluated the number of opening and ventilation system at four selected religious buildings (Masjid) as shown in Table 1 below in Kelantan, Malaysia shown in Table 1.

Table 1.

The geographic information of selected religious buildings in suburban area of Kelantan, Malaysia

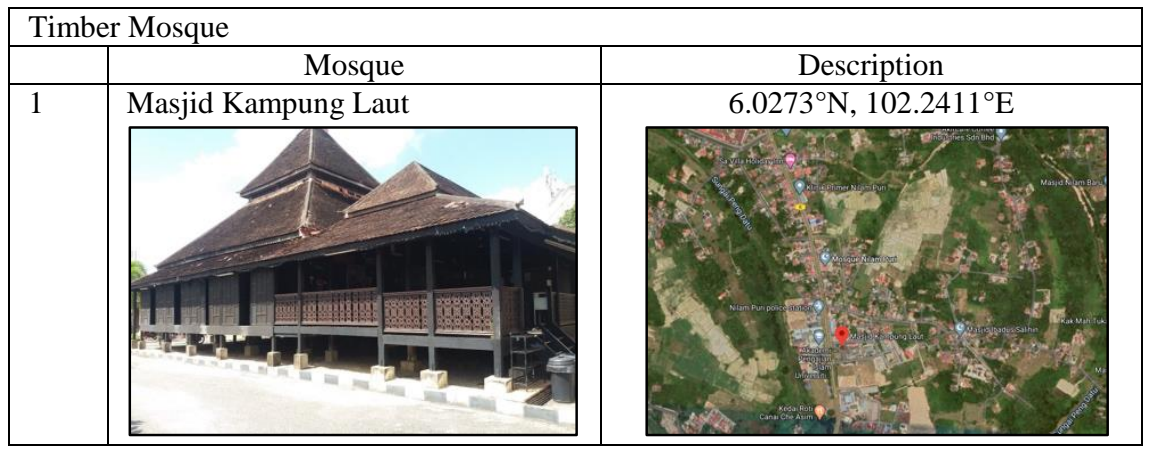




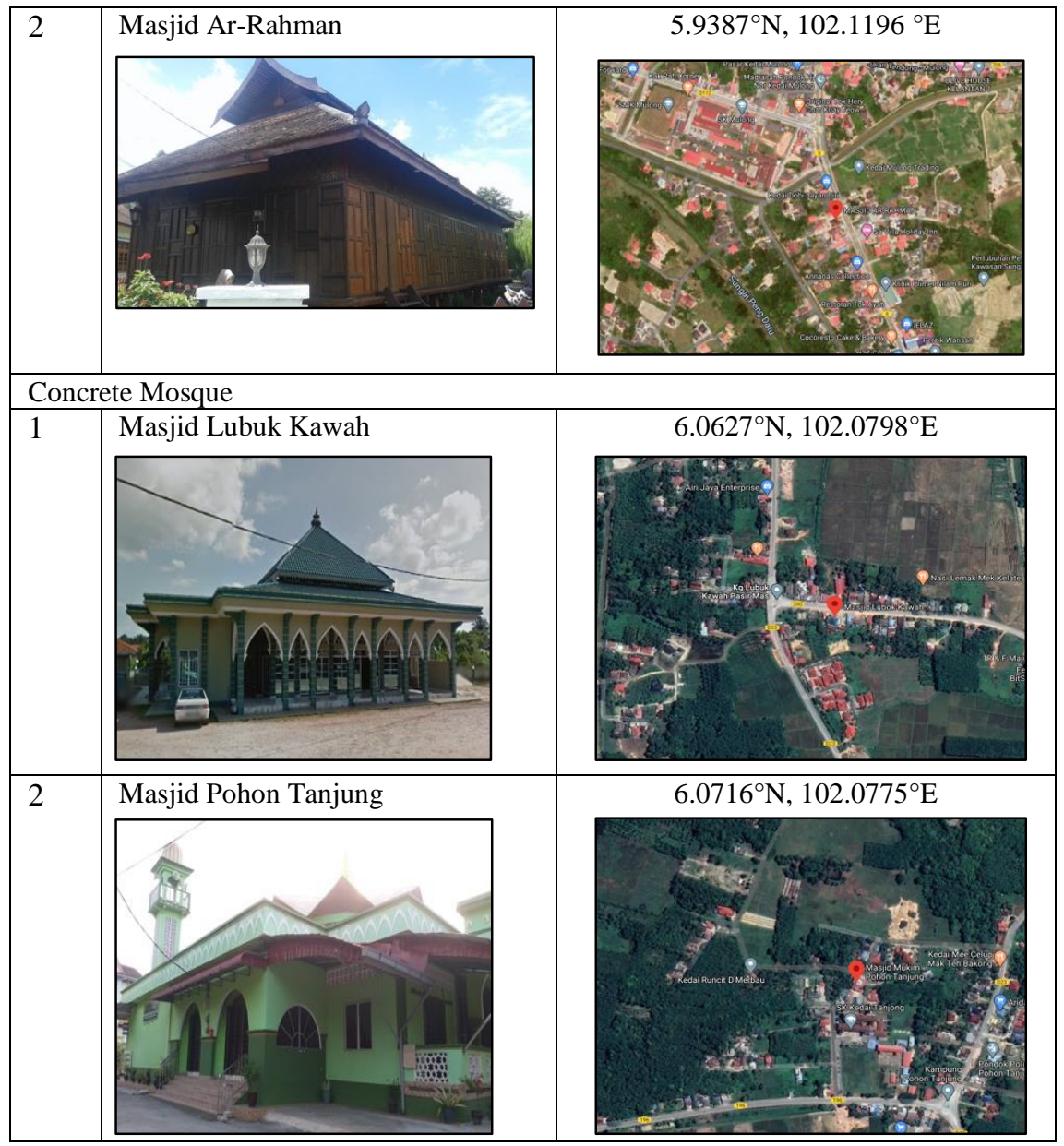

Out of available methods for collecting primary data, survey and case study have been found suitable for the topic study. These have fulfilled the requirements for the data collection properly. Meanwhile, Fig. 1 below portrays the conceptual research model for this research. It is theorized that there are environmental factors which can be related to thermal comfort and worshippers' perception in the mosques as follows:

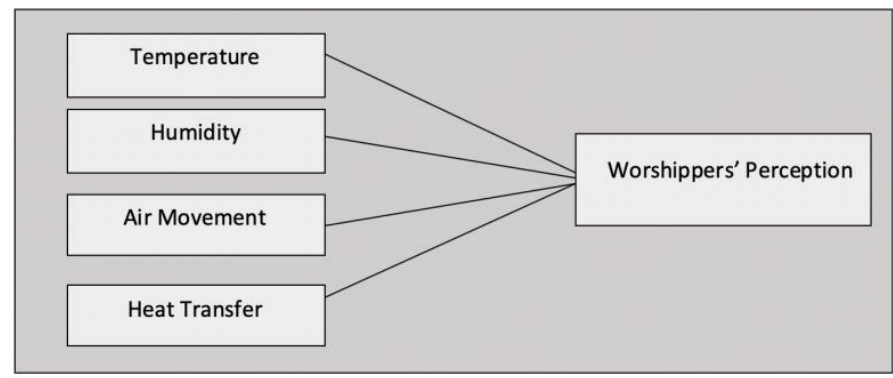

Fig. 1. Research Framework (adapted from Tharim, Samad \& Ismail, 2018) 


\section{RESULTS AND DISCUSSION}

The purpose of this chapter is to describe the result from the analysis and the finding obtained from the data collection process, which is a questionnaire survey. It is explained through the two objectives of the study.

\subsection{Objective 1: To Compare the Thermal Comfort Condition between Timber and Concrete Mosque.}

Table 2.

The analysis of the overall comparison of timber and concrete mosques in term of thermal comfort condition

\begin{tabular}{|l|c|c|c|}
\hline \multicolumn{1}{|c|}{ Questions } & Timber & Concrete & \multirow{2}{*}{ Rank } \\
\cline { 2 - 3 } & \multicolumn{2}{|c|}{ Mean } \\
\hline Temperature & 3.82 & 3.78 & 3 \\
\hline Satisfied with the temperature Condition & 3.68 & 3.89 & 2 \\
\hline Comfortable with the ventilation system & 3.79 & 3.96 & 1 \\
\hline Need more cool air & 2.89 & 1.87 & 2 \\
\hline More warm air & 3.48 & 3.67 & 2 \\
\hline Humidity & 3.86 & 3.90 & 1 \\
\hline Satisfied with the overall humidity & 3.37 & 3.54 & 3 \\
\hline Comfortable when the window is opened & 3.00 & 2.43 & 4 \\
\hline More humidity (air is too dry) & 3.61 & 3.63 & 3 \\
\hline Less humidity (air is too wet) & 3.49 & 3.71 & 1 \\
\hline Air Movement & 3.36 & 3.70 & 2 \\
\hline Air movement (ventilation) available. & 2.78 & 2.29 & 4 \\
\hline I think that the window size is all right for me & 3.37 & 3.34 & 2 \\
\hline I need more air movement & 3.36 & 3.53 & 1 \\
\hline I need less air movement & 3.17 & 3.03 & 3 \\
\hline Heat Transfer & 3.65 & 3.92 & 1 \\
\hline Incoming sun & 3.71 & 3.86 & 2 \\
\hline Hot wall/ window surfaces & 3.72 & 3.92 & 1 \\
\hline Heat sources from ventilation system (e.g. Fans) & \\
\hline Worshippers' Satisfaction & \\
\hline The overall thermal comfort level & \\
\hline The overall quality of indoor ventilation & \\
\hline I'm greatly satisfied with this mosque building & \multicolumn{2}{|l}{} \\
\hline
\end{tabular}

The result from Table 2 above indicated the thermal comfort condition in between timber and concrete mosque consists of four factors of thermal comfort and the satisfaction in mosque building has been analyzed.

\subsubsection{Temperature}

From the analysis, worshippers agreed that they needed more cold air $(M=3.96)$ in the concrete mosque than timber mosques $(M=3.79)$. In addition, the data recorded that the worshippers were more satisfied with the temperature $(M=3.82)$ in the timber mosque than the concrete mosque $(\mathrm{M}=3.67)$. However, the data also shows that the ventilation system in the concrete mosque is more comfortable $(\mathrm{M}=3.89)$ than timber mosques $(\mathrm{M}=$ 
3.68). Finally, hot air does not need to be in the concrete mosque where mean values record the lowest value $(\mathrm{M}=1.87)$ in concrete and $(\mathrm{M}=2.89)$ in timber mosque.

\subsubsection{Humidity}

The concrete mosque recorded the highest value in the humidity factor is where the worshippers felt more comfortable when the window was opened $(\mathrm{M}=3.90)$ and satisfied with the overall humidity $(M=3.67)$ also required more humidity $(M=3.54)$ instead of mosques by the score of the more comfortable when the window is opened $(\mathrm{M}=3.86)$ and satisfied with the overall humidity $(\mathrm{M}=3.48)$ also requires more moisture $(\mathrm{M}=3.37)$. However, the highest value for timber mosque is the need for less humidity $(\mathrm{M}=3.00)$ other than concrete mosque $(\mathrm{M}=2.43)$.

\subsubsection{Air Movement}

The results show the window size of the concrete mosque $(M=3.71)$ are more satisfied than timber mosque $(M=3.49)$. In addition, the need more air movement $(M=3.70)$ in the concrete mosque and $(\mathrm{M}=3.36)$ in timber concrete with the air movement ventilation available in the mosque $(\mathrm{M}=3.63)$ for concrete and $(\mathrm{M}=3.61)$ for timber mosque.

\subsubsection{Heat Transfer}

The Hot wall/ window surfaces are more affecting the thermal comfort of worshippers in timber mosque $(M=3.53)$ other than concrete mosque $(M=3.36)$. In addition, the incoming of the sun in timber mosque $(\mathrm{M}=3.37)$ and a concrete mosque $(\mathrm{M}=3.34)$ was recorded as the second higher in heat transfer followed by heat sources from ventilation system which is timber mosque $(\mathrm{M}=3.17)$ and a concrete mosque $(\mathrm{M}=3.03)$.

\subsubsection{Worshippers' Satisfaction}

The analysis found that the worshippers' perception level in concrete mosques is higher than timber mosques which has a mean score of $M=3.92$ in terms of their overall thermal comfort level and satisfaction with the mosque. The worshippers' also give the good result for the overall quality of indoor ventilation where the score of the mean is still high where the mean is 3.86 for concrete and the mean=3.71 for timber mosques.

\subsection{Objective 2: To Analyze the Relationship Between Thermal Comfort and Worshippers' Perception Level in the Mosque Building}

\subsubsection{Multiple Regression Analysis}

By using multiple regression analysis methods, this analysis indicates the direction of the relationship, which is positive or negative. The multiple regression analysis displays the coefficient table comprises significance values and beta value. The significance level (or pvalue) is the probability of obtaining results as extreme as the one observed. If the significance level is very small (less than 0.05), the relationship is significant, and the two variables are linearly related. However, if the significance level of the coefficient table is relatively large (above 0.05), the relationship is not significant, and the two variables are not linearly related. In this study, multiple regression analysis was conducted to examine the relationship between worshippers' satisfaction and factor affecting thermal comfort in mosque building. 
Table 3.

Descriptive statistics on the agreed factors

\begin{tabular}{|l|c|c|c|l|}
\hline \multicolumn{1}{|c|}{ Hypothesis } & t & Sig & Beta & Hypothesis Finding \\
\hline Temperature & 6.150 & .000 & .428 & Supported \\
\hline Humidity & 0.613 & .540 & .058 & Not Supported \\
\hline Air movement & 7.916 & .000 & .721 & Supported \\
\hline Heat Transfer & 4.200 & .000 & .212 & Supported \\
\hline
\end{tabular}

*R2 adjusted value 0.457 (model) $\quad *$ P value $>0.05 /$ t. $>1.96$

\subsubsection{Hypothesis Testing}

From Table 3, the result from multiple regression analysis has shown that the three variables were found to be consist of a significant level where $p>0.05$. The first variable is air movement followed by temperature and finally, heat transfer. The humidity variables are not significant and not supported by the hypothesis. This is because the $\rho$ value is more than 0.05 . Thus, the hypothesis of temperature, air movement and heat transfer are accepted in this research.

\subsubsection{Determining the model fits}

The model summary table provides the R, R2, adjusted R2, and the standard error of the estimate, which can be used to determine how well a regression model fits the data:

Model Summary

Table 4.

\begin{tabular}{|c|c|c|c|c|}
\hline Model & R & R Square & $\begin{array}{l}\text { Adjusted R } \\
\text { Square }\end{array}$ & $\begin{array}{l}\text { Std. Error of the } \\
\text { Estimate }\end{array}$ \\
\hline 1 & $.685 \mathrm{a}$ & .469 & .457 & .50629 \\
\hline
\end{tabular}

The value of 0.469 is that independent variables explain $46.7 .9 \%$ of the variability of the dependent variable is influenced by model variables. Furthermore, the result was interpreted into adjusted $\mathrm{R}$ square to get the accurate data of the analysis. Based on SPSS Version 23.0, the result showed that $45.7 \%$ (model) worshipper's satisfaction is influenced by model variables which are thermal comfort factor, and thus $54.3 \%$ is from an external factor.

\subsubsection{Determined model coefficients}

To get the result for the statistical significance of each of the independent variables whether the unstandardized (or standardized) coefficients are equal to 0 (zero) in the population. If $\mathrm{p}<.05$, it can be concluded that the coefficients are statistically significantly different to 0 (zero). The $t$-value and corresponding p-value are located in the " $t$ " and "Sig." columns. Table 4 shows the temperature, air movement and heat transfer were significant of each of the independent variables where the coefficients are equal to 0 (zero). The above table is a summary of descriptive statistics and analysis results. The temperature, air movement and heat transfer factor are positively and significantly correlated with the criterion, indicating that those worshipper's satisfaction. Humidity is negatively correlated with worshipper's satisfaction with a score of 0.540 , where it exceeded $p<0.05$. It can be concluded that temperature, air movement, heat transfer has a positive relationship with worshippers' satisfaction. However, the humidity variables are considered as having a 
negative relationship with worshipper satisfaction. Furthermore, unstandardized coefficients indicate how much the dependent variable varies with an independent variable when other independent variables are held constant (considering the effect of temperature, humidity, air movement and heat transfer). From the beta value, the most dominant variable is air movement followed by temperature and heat transfer. Air movement result scored the highest value $(0.721)$ followed by temperature $(0.428)$ and heat transfer $(0.212)$.

Table 5.

Coefficients Table

\begin{tabular}{|l|cc|c|c|c|}
\hline \multirow{2}{*}{ Model } & \multicolumn{2}{|c|}{$\begin{array}{c}\text { Unstandardized } \\
\text { Coefficients }\end{array}$} & $\begin{array}{c}\text { Standardized } \\
\text { Coefficients }\end{array}$ & \multirow{2}{*}{$\mathbf{t}$} & \multirow{2}{*}{ Sig. } \\
\cline { 2 - 4 } & $\mathbf{B}$ & $\begin{array}{c}\text { Std. } \\
\text { Error }\end{array}$ & Beta & & \\
\hline Temperature & .428 & .070 & .397 & 6.150 & .000 \\
\hline Humidity & .058 & .095 & .040 & 0.613 & .540 \\
\hline Air movement & .721 & .091 & .499 & 7.916 & .000 \\
\hline Heat Transfer & $\begin{array}{c}.212 \\
.051\end{array}$ & .257 & 4.200 & .000 \\
\hline
\end{tabular}

Majority of the respondents have chosen the concrete mosque as their preference to perform prayer instead of timber mosque. Referring to the data, the worshippers are satisfied with the humidity factors, comfortable with the ventilation system, air movement and satisfied in overall building condition and environment inside the concrete building. Based on the data analysis, timber and concrete mosque significantly effects on worshippers' perception level. The data has shown that temperature, humidity and satisfaction have a positively and significantly correlated with the different type of the mosque's building. The majority of the respondents have good perception level towards timber mosque rather than concrete mosque where the temperature, humidity, heat transfer is greater than the concrete mosque. In addition, the concrete mosque also scores a higher result compared to timber mosque in term of worshippers' satisfaction and air movement.

\section{CONCLUSIONS}

Based on the results of the survey and case study finding, the overall worshippers were satisfied with the thermal comfort level in timber and concrete mosques. However, the need for improving thermal comfort for the concrete mosque is higher than the timber mosque. Based on descriptive statistics, the data analysis has shown that the demand of the worshippers in improving thermal comfort condition in terms of temperature, humidity, air movement is more crucial in regards to the local climate (hot and humid). In addition, most of the respondents (worshipper) are satisfied with the ventilation and opening of both mosques where the size and types of the opening and ventilation are applicable and significant in providing the thermal comfort. This research can be referred to as a guideline to the Architects and developers in designing and constructing the building in regards to the satisfaction of the clients or people and according to the local climate which is hot and humid. The design and architecture of the building have significantly contributed to the overall satisfaction of occupants and users. 


\section{R E F E R E N C E S}

Al-Homoud, M. S., Abdou, A. A., and Budaiwi, I.M. (2009). Assessment of Monitored Energy Use and Thermal Comfort Conditions in Mosques in Hot-Humid Climates. Energy and Buildings. 41(6): 607-614.

ASHRAE Standard 55 (2013) Thermal Environmental Conditions for Human Occupancy. ASHRAE. Atlanta, USA.

ASHRAE Standard 55 (2004) Thermal Environmental Conditions for Human Occupancy. American Society of Heat, Refrigerating, and Air-Conditioning Engineers. Inc., Atlanta, GA.

Asif, N., Utaberta, N., \& Sarram, A. (2019). Urban Mosque in the Compact City of Kuala Lumpur: Suitability and Design Considerations. Geographia Technica 14, Special Issue, 138-147. DOI: 10.21163/gt_2019.141.27

Hussin, A., Salleh, E., Chan, H.Y. \& Mat. S., (2014). Thermal Comfort during Daily Prayer Times in an Air-Conditioned Mosque in Malaysia. Proceedings of 8th Windsor Conference: Counting the Cost of Comfort in a Changing World.

Jamaludin, N., Mohammed, N.I., khamidi, M.F and Abdul Wahab, S.N. (2015). Thermal Comfort of Residential Building in Malaysia at Different Micro-Climates. Asian Conference on Environment-Behaviour Studies Chung-Ang University, Seoul, S. Korea, 25-27 August 2014. Pp.613-623.

Maarof, S., (2014), Roof Designs And Affecting Thermal Comfort Factors In A Typical Naturally Ventilated Malaysian Mosque. Cardiff University School of Architecture.

Nasir, A.H. (1984). Mosque of Peninsular Malaysia. Petaling Jaya: Berita Publishing Sdn. Bhd.

Omer, S. (2010). Some Lessons from Prophet Muhammad (SAW) in Architecture: The Prophet's Mosque in Madinah. Intellectual Discourse, 18(1), 115-140.

Qahtan, A. M., Keumala, N. I. M. \& Rao, S. P. (2010) Occupant satisfaction in respect to indoor environmental quality in energy efficient certified buildings in Malaysia. 16th International Conference of the CIB W104 Open Building Implementation on "Open and Sustainable Building”. Bilbao, Spain, CIB W104.

Senkal Sezer, F. \& Kaymaz, E. (2016). The User's Perception of Indoor Comfort Conditions in Historical Mosques: The Case of Bursa, Turkey. International Journal of Humanities and Social Science, 6 (9).

Soemardiono, B., Rachmawati, M., Ardianta, D. A., \& Nugroho, S. (2019). Spatial Analysis Of Urban Dense Area In Developing Criteria Design Based On People Participation: A Case Study Of Kembang Jepun, Surabaya. Geographia Technica, 14, Special Issue, 13-21, DOI: 10.21163/Gt_2019.141.14

Tharim, A. A. H., Samad, A. M. H \& Ismail, M. (2018). Relationship between IEQ and Occupant's Satisfaction in Malaysia Rated Office Building: A Pilot Study, Regional Conference on Science, Technology and Social Sciences (RCSTSS).

Zafrullah, M. T. (2011). Thesis PhD 'Persepsi masyarakat Melayu terhadap ruang kesucian Masjid'. Universiti Teknologi Malaysia. EUROSTAT DATABASE (2017). - Available from: http://ec.europa.eu/eurostat/.[Accessed March 2017]. 